\title{
PREDICTION OF PLANTING DATE AND GROWING PERIOD USING SEA SURFACE TEMPERATURE (SST) ANOMALIES IN NINO 3.4 FOR INDRAMAYU DISTRICT
}

\author{
Rini Hidayati* and Daniel Naek Chrisendo
}

\author{
Laboratorium Klimatologi, Dept. Geofisika dan Meteorologi IPB \\ Gedung FMIPA Wing 19 Lv. 4 Kampus IPB Darmaga, Bogor 16680 \\ * Corresponding Author. E-mail: rinihid@yahoo.com
}

Penyerahan Naskah: 17 Maret 2010

Diterima untuk diterbitkan: 7 Juni 2010

\begin{abstract}
Agriculture is a very important sector in Indramayu's economy. Approximately $53.52 \%$ of Indramayu residents are involved in agriculture. Indramayu is a center of rice production in Indonesia. Most of the farmers use a traditional cropping method called Pranata Mangsa, which is based on periodic natural events, but not consider climate variability well. Climate variability has become a major obstacle to achieving a successful harvest, because it can affect the timing of planting and length of the growing season, which leads to drought and flood vulnerability. The planting date and growing season predicted by using monthly sea surface temperature anomalies (SSTa) in Nino 3.4. The August SSTa can describe the planting date better than the growing season, which are demonstrated best in Lohbener with $\mathrm{R}^{2}=45 \%$ with forecast skill reach $=$ $84 \%$ and $92 \%$ for advanced and delayed planting dates. Knowing the planting date and growing season length produce a more effective cropping calendar, which includes details such as when to prepare the land, plant seeds, and harvest. This cropping calendar is expected to reduce the impacts of climate variability by providing a more efficient cropping pattern and avoiding potential harvest failures.
\end{abstract}

Keyword: cropping calendar, growing season, palnting date, SST anomalies

\section{INTRODUCTION}

Indramayu is an administrative district in West Java, has a total land area of $204.011 \mathrm{Ha}$, with $119.752 \mathrm{Ha}$ (around 58\%) being rice fields (BPS 2009) make Indramayu as a center of rice production in Indonesia. Agriculture in this region very influenced by rainfall variability. This region has a monsoonal rainfall pattern, with significant different in rainfall between rainy and dry season. Most of the monsoonal rainfall pattern regions in Indonesia Impact of SST in Nino3.4 region.

Sea surface temperature anomalies (SSTa) in the equatorial central Pacific (Nino 3.4) is one indicator of ENSO, which is a global phenomenon of oceanatmosphere system. Influence to rainfall variability in Indonesia regions. The wetter conditions are associated with the high index phase of Southern Oscillation for July to December season, and rainfall are more than normal during dry season in this condition (Ropelewski and Halpert 1989)

Rice plants are vulnerable to drought because rice cultivation requires relatively much water.
Naylor et al. (2001) obtain a negative relationship between SSTa with rainfall and rice production. SSTa is more useful information to predict the growing season and rice production than rainfall information. In Luson, Phillipines, SSTa information at an earlier period (July-September) then the period of rainfall (October-December), can be used to predict the beginning of the growing season and rice production (Robert et al. 2008).

For agricultural crops in Java, information about the onset of the rainy season is also needed primarily to establish a strategy of planting (Naylor et al. 2007). Onset and length of rainy season needed to determine the start and length of growing season in Indonesia and other countries is often associated with ENSO conditions index (Hansen et al. 1998; Naylor et al. 2002; Naylor et al. 2007). Adams et al. (2003) also been reported that ENSO information could be used to help farmers to change cropping patterns that farmers avoid the risk of loss and increase economic benefits.

Naylor et al. (2001) used data Niño 3.4 SSTa in August to explain the $66 \%$ rainfall data variability in 
September to December in Indonesia, connecting with the planting area, harvested area and production, and found that August SSTa fluctuations from year to year can explain 50\% annual variability of rice and corn production in Indonesia. Moron et al. (2009) found that early-West Monsoon, which is associated with the onset of rainy season in Indonesia, can be predicted by using either the SSTAs in July.

The most of Indramayu farmers have a cropping habit called "Pranata Mangsa" which is based on regular natural events. Knowledge about Pranata Mangsa is propagated hereditarily. It is generally correct as long as there is no changes or irregularities such climate variability, which can lead to harvest failure. Due to this limitation, it necessary to review how the existing cropping habit fits with climate variability. In order to achieve successful agricultural production especially in the rainfed and limited irigation paddy fields, it is necessary to design a cropping calendar that accounts for climate variability.

The purpose of this research is to determine the beginning and length of growing season in Indramayu in various conditions of Sea Surface Temperature Anomaly in Nino 3.4.

\section{METHODS}

\section{Research Materials}

Materials used in this research were:

1. Decade rainfall data for sub-districts in Indramayu from 1979-2009

2. Decade temperature data for Pusakanegara, Subang from 1979-2009

3. SST anomalies data in Nino 3.4 for August from 1979-2009

4. Permanent wilting point and field capacity

\section{Research Methods}

\section{Climate Data Collection and Farmer Interviews}

Preparation for this research began with gathering the rainfall data for Indramayu from 19792009, temperature data for Subang from 1979-2009, monthly sea surface temperature (SST) anomalies for August from 1979-2009.

The rainfall data was obtained from the Water Management Agency for Indramayu. There are no weather stations in Indramayu that measures the temperature, so temperature data for Subang District collected by the Indonesian Agroclimate and Hydrology Research Institute, Bogor, was used with the assumption that Subang and Indramayu have the same elevation and are close geographically which makes the temperature data for Subang valid for Indramayu. The SST anomalies in Nino 3.4 were obtained from the National Oceanic and Atmospheric Administration (NOAA) website (http://www.cpc.noaa.gov/). Interviews with farmers were conducted in three sub districts in Indramayu; Lelea, Cikedung and Trisi, with a total of 150 farmers interviewed.

\section{Determining the Observation Area}

The observation area was determined by using the rainfall clustering in Indramayu determined by Meteorology, Climatology, and Geophysics Agency, as the following: Bondan for cluster no.1, Bangkir for no.2, Cigugur or Bugel for no.3, Lohbener for no.4, Bulak for no.5, Cikedung for no.6 (Haryoko 2008). Because of the difficulty obtaining the rainfall data for Cigugur or Bugel, cluster no. 3 was ignored.

\section{Determining the Daily PET}

The daily potential evapotranspiration (PET) was derived by first obtaining the monthly PET. The monthly PET was obtained by using the Thornthwaite model. According to White and Host (2002):

- For temperature $<26.5^{\circ} \mathrm{C}$

$P E T=1.6\left(10 \frac{t}{I}\right)^{a}$

PET = monthly potential evapotranspiration $(\mathrm{cm})$

$\mathrm{t} \quad=$ mean monthly temperature $\left({ }^{\circ} \mathrm{C}\right)$

I $=$ a heat index for a given area which is the sum of 12 monthly index values $i, i$ is derived from monthly temperatures using the following formula:

$\mathrm{I}=\sum_{\mathrm{i}=1}^{12}\left(\frac{\mathrm{t}}{5}\right)^{1.514}$

A $=$ an empirically derived exponent which is a function of $I$, which can be derived from:

$$
\begin{aligned}
a=0.000000675 & \mathrm{I}^{3}-0.0000771 \mathrm{I}^{2} \\
& +0.01792 \mathrm{I}+0.49239
\end{aligned}
$$

- $\quad$ For temperature $\geq 26.5^{\circ} \mathrm{C}$

$$
\text { PET }=-0.0433 \mathrm{t}^{2}+3.2244 \mathrm{t}-41.545
$$

PET values were scaled on a latitudinal gradient based on mean duration of sunlight in 12-hour units, so that the PET needs to be adjusted by using the following formula:

PET $($ adjusted $)=$ PET $\times \mathrm{F}$ 
$F$ is correction factor (Table 1). After calculating the monthly PET, the daily PET can be derived by using a climate data generator. Epstein (1991) in Narapusetty et al. (2010) developed a procedure to obtain daily climate data from monthly data using Fourier series regressions as denoted in the following equation:

$P\left(t^{*}\right)=a_{0}+\sum_{k=1}^{n}\left[a_{k} \sin \left(k t^{\prime}\right)+b_{k} \cos :\left(k t^{\prime}\right)\right]$

$\mathrm{t}^{*}=$ daily temperature

$\mathrm{a} 0, \mathrm{ak}, \mathrm{bk}=$ Fourier coefficient

$\mathrm{k}=$ number of anual harmonics

$\mathrm{t}^{\prime}=\frac{2 \pi \mathrm{t} *}{12}$ with $\mathrm{t}^{*}$ is temperature from the following equation:

$\mathrm{t}^{*}=\frac{(\mathrm{T}-0.5)+(\mathrm{m}-0.5)}{\mathrm{D}}$

$\mathrm{T}=$ month

$\mathrm{m}=$ days in month $\mathrm{T}$

$\mathrm{D}=$ number of days in month $\mathrm{T}$.

Table 1. Correction factor for latitude

\begin{tabular}{ccc}
\hline Month & \multicolumn{2}{c}{$\left(^{\mathbf{0}}\right)$ South } \\
& $\mathbf{6}$ & $\mathbf{7}$ \\
\hline Jan & 1,06 & 1,07 \\
Feb & 0,95 & 0,96 \\
Mar & 1,04 & 1,04 \\
Apr & 1 & 1 \\
Mei & 1,02 & 1,02 \\
Jun & 0,99 & 0,98 \\
Jul & 1,02 & 1,02 \\
Agust & 1,03 & 1,03 \\
Sep & 1 & 1 \\
Okt & 1,05 & 1,05 \\
Nop & 1,03 & 1,04 \\
Des & 1,06 & 1,07 \\
\hline
\end{tabular}

\section{Testing the Forecast Skill}

WMO recommended using Relative Operating Characteristics (ROC) for probabilistic forecast verification (Mason and Graham 1999 in Boer 2006) which can be formed by plotting the false alarm rate (FAR) and hit rate (HR) values.

- Calculating the Hit Rate (POD, probability of detection).

POD $=$ hits $/($ hits + misses $)$

hits $=$ the forecast said the event would happen and it does happen

miss $=$ forecast said the event would not happen and it does happen
Interval values ranged from zero to one, as the perfect score.

- Calculating the FAR (POFD, probability of false detection).

POFD $=$ fals alarms $/($ correct negatives + fals alarms $)$

false alarm $=$ forecasts said the event would happen and it does not happen

correct negative $=$ forecasts said the event would not happen, and it really does not happen

Interval values ranged from zero to one, with zero as the perfect score.

- Plotting the FAR vs HR table into ROC curve

- If the line coincide with the non skill line, it means that there is no skill

- If the line is above the non skill line, it means positive skill (reliable)

- If the line is below the non skill line, it means negative skill (non-reliable)

- Reliability score is the area below the curve line. Number of squares below the curve line is divided with the total squares, known as the score skill.

\section{Determining the Planting Date and Growing Season}

To determine the cropping time, the soil water balance must first be calculated using the following equation: Rainfall $=$ PET + Surplus/Deficit

Using the equation above, the soil moisture content and water holding capacity can also be derived. The soil moisture content, water holding capacity, permanent wilting point, and field capacity can be used to determine the planting date and the growing season. The permanent wilting point and the field capacity are $210 \mathrm{~mm}$ and $350 \mathrm{~mm}$ respectively (Pawitan et al. 1997)

\section{Determining the Planting Date and Growing Season Equation Based on SST Anomalies}

Calculating the proper time to plant and growth potential takes into consideration the SST anomalies. The equation to predict planting date was derived using the correlation between SST anomalies in certain months with planting date and growing season. The strength of correlation in the model can be seen from its R squared, while the accuracy can be seen from its forecast skill. 


\section{RESULT AND DISCUSSION}

\section{Social Data for Indramayu}

Based on the interviews, $82.67 \%$ of the farmers plant rice during the first two growing season and they leave their land to fallow during the third season. This trend can be attributed to superior water availability from rainfall during the first and second seasons. As a result of this diminishing water availability, $5.3 \%$ of the respondents plant rice only during the first growing season and leave their fields to fallow for the remainder of the seasons. However, approximately $6 \%$ of the respondents take the risk to plant a secondary crop during the third season. According to the Indramayu farmers sampled, the tillage and seed preparation usually occurred during the three decades prior to the planting date.

Around $52 \%$ of the respondents use Ciherang rice variety, while $18.7 \%$ use a local variety called Kerbau which has not been published yet, and the remaining 30\% use other varieties. The majority of Indramayu rice farmers use Ciherang because it is recommended by the agricultural extension office and due to the typically good quality production of this particular rice variety. Ciherang is resistant to disease, heavy rain, and excessive sun, it is quick to harvest, and it fetches a good price at the market. Farmers use Kerbau because it produces more rice. However, an extreme climate year which leads to flood or long drought, can result in complete harvest failure.

\section{Average Condition of Surplus and Deficit}

The distribution of surplus and deficit values demonstrates the water availability. The average condition of decadal water surplus and deficit for Indramayu during the year is shown in Figure 1.

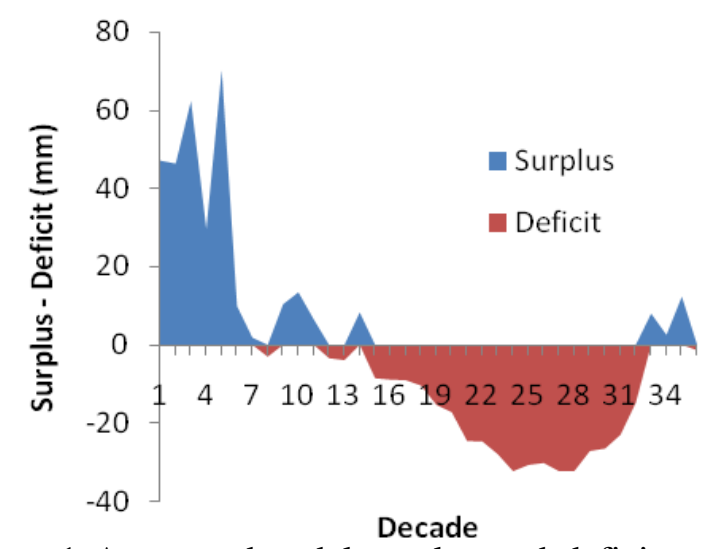

Figure 1 Average decadal surplus and deficit value for 5 clusters in Indramayu.

The average condition of surplus and deficit in Indramayu for last ten years shows that the period of surplus begins on approximately decade 33 and ends on decade 14. This finding can be explained by Indramayu's rainfall which is characterized by the monsoon, with the peak of rainy season occurring at the beginning of the year and the peak of the dry season (low rainfall) occurring midyear. The average decadal surplus value can reach up to $40 \mathrm{~mm}$, and the deficit can reach as low as $-36 \mathrm{~mm}$ (Figure 1).

The distribution of onset, lenght, and intensity of surplus session varied in every location. Bondan sub-distict has the most delayed and the longest surplus session, reaching up to 17 decades, while Bulak and Lohbener have the shortest ones at 14 decades. Lohbener reached the highest surplus value about $96 \mathrm{~mm}$ and Bangkir reaches the highest deficit value at about $-31 \mathrm{~mm}$.

\section{Average Water Balance}

The average water balance of five clusters in Indramayu during the year can be shown by Figure 2.

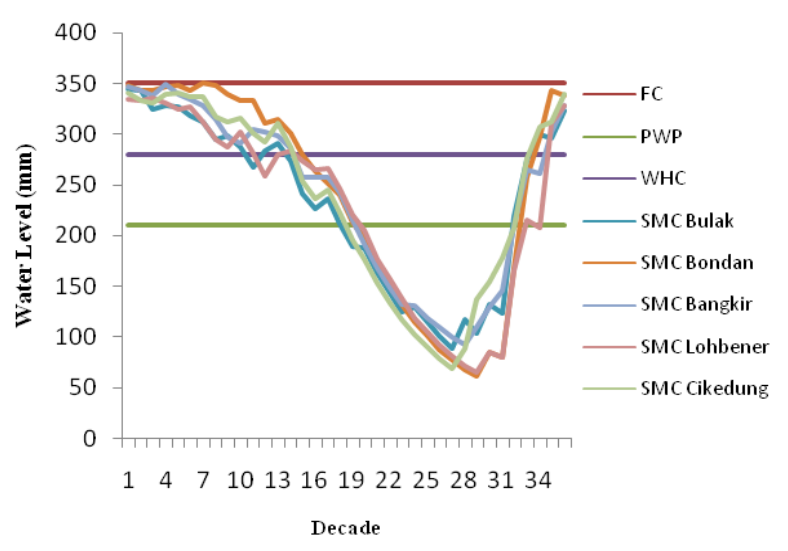

Figure 2 Average decadal water balance for 5 rainfall clusters in Indramayu.

Generally, the availability of water for planting starts on decade 35 , and the water begins to run out after decade 14 , or 16 . In decade 35 , when the soil moisture content level exceeds the water holding capacity level, it can be considered the planting date. On decade 15 , the soil moisture content level is lower than the water holding capacity level and continues decreasing until it is lower than the permanent wilting point. This condition is only for crop harvest (Figure 2).

More detail, Bangkir, Lohbener, and Bulak, which are located in the north and center of Indramayu have 16 decades of available water, while Bondan and Cikedung which are located on the southern part have one decade longer of available water. This is due in part to the region's topography. The southern part of Indramayu is a higher location which makes the rainfall higher because of the orographic process, creating more water surplus, and extending the time of water availability. 


\section{Planting Date and Growing Season}

The planting date and growing season for five clusters in Indramayu over the previous ten years can be explained in more detail by Tables 2 and 3 . Bondan, Bangkir, Bulak and Cikedung have planting date, approximately on decade 31 for the past thirty years, one decade ahead of Lohbener. By year, the planting date for all areas became more advanced in 1979/1980. On the contrary, the most delayed planting date happened on 1997/1998 and 2006/2007, due to the El Nino that happened those years. Overall, the planting date does not show the great variability (Table 2 ) across clusters.

Table 2. Planting date for five clusters in Indramayu 2000-2009

\begin{tabular}{ccccccc}
\hline Year & Bondan & Bangkir & Lohbener & Bulak & Cikedung & Average \\
\hline $79 / 80$ & 27 & 27 & 27 & 27 & 27 & 27 \\
$80 / 81$ & 30 & 30 & 31 & 31 & 30 & 30 \\
$81 / 82$ & 31 & 32 & 27 & 27 & 27 & 29 \\
$82 / 83$ & 34 & 33 & 36 & 31 & 31 & 33 \\
$83 / 84$ & 30 & 29 & 30 & 30 & 30 & 30 \\
$84 / 85$ & 29 & 28 & 30 & 24 & 24 & 27 \\
$85 / 86$ & 29 & 27 & 27 & 29 & 29 & 28 \\
$86 / 87$ & 30 & 31 & 31 & 26 & 29 & 29 \\
$87 / 88$ & 33 & 32 & 33 & 33 & 32 & 33 \\
$88 / 89$ & 30 & 29 & 29 & 29 & 29 & 29 \\
$89 / 90$ & 32 & 31 & 32 & 30 & 30 & 31 \\
$90 / 91$ & 33 & 35 & 35 & 34 & 33 & 34 \\
$91 / 92$ & 32 & 31 & 32 & 31 & 32 & 32 \\
$92 / 93$ & 25 & 31 & 29 & 28 & 25 & 28 \\
$93 / 94$ & 29 & 32 & 32 & 32 & 37 & 32 \\
$94 / 95$ & 32 & 33 & 34 & 37 & 32 & 34 \\
$95 / 96$ & 27 & 30 & 30 & 31 & 30 & 30 \\
$96 / 97$ & 28 & 25 & 30 & 30 & 29 & 28 \\
$97 / 98$ & 35 & 35 & 35 & 34 & 35 & 35 \\
$98 / 99$ & 28 & 30 & 29 & 31 & 30 & 30 \\
$99 / 00$ & 29 & 30 & 29 & 32 & 30 & 30 \\
$00 / 01$ & 30 & 31 & 30 & 32 & 32 & 31 \\
$01 / 02$ & 32 & 29 & 32 & 24 & 28 & 29 \\
$02 / 03$ & 33 & 36 & 33 & 36 & 34 & 34 \\
$03 / 04$ & 32 & 33 & 32 & 32 & 29 & 32 \\
$04 / 05$ & 33 & 33 & 33 & 33 & 33 & 33 \\
$05 / 06$ & 33 & 32 & 35 & 33 & 29 & 32 \\
$06 / 07$ & 34 & 35 & 35 & 34 & 36 & 35 \\
$07 / 08$ & 35 & 30 & 32 & 28 & 30 & 31 \\
$08 / 09$ & 34 & 35 & 35 & 30 & 31 & 33 \\
$09 / 10$ & 32 & 32 & 36 & 32 & 33 & 33 \\
\hline Average & 31 & 31 & 32 & 31 & 31 & 31 \\
& & & & & &
\end{tabular}

Bulak has the shortest growing season, 20 decades on average, while Bangkir average 22 decades. During 1990/1991, the growing season only reached approximately 16 decades, while the 1984/1985 lasted 28 decades, the longest growing season during the years (Table 3 ). These are due to the occurred El Nino and La Nina during those years.
Table 3. Growing season for five clusters in Indramayu 2000-2009

\begin{tabular}{|c|c|c|c|c|c|c|}
\hline \multirow{2}{*}{ Year } & \multicolumn{6}{|c|}{ Growing Season } \\
\hline & Bondan & Bangkir & Lohbener & Bulak & Cikedung & Average \\
\hline $79 / 80$ & 23 & 24 & 20 & 24 & 22 & 23 \\
\hline $80 / 81$ & 22 & 21 & 17 & 20 & 27 & 21 \\
\hline $81 / 82$ & 20 & 16 & 22 & 22 & 21 & 20 \\
\hline $82 / 83$ & 20 & 21 & 18 & 23 & 22 & 21 \\
\hline $83 / 84$ & 20 & 29 & 36 & 22 & 24 & 26 \\
\hline $84 / 85$ & 21 & 31 & 29 & 25 & 35 & 28 \\
\hline $85 / 86$ & 25 & 28 & 28 & 26 & 20 & 25 \\
\hline $86 / 87$ & 23 & 23 & 23 & 22 & 22 & 23 \\
\hline $87 / 88$ & 22 & 23 & 22 & 22 & 16 & 21 \\
\hline $88 / 89$ & 26 & 32 & 26 & 28 & 29 & 28 \\
\hline $89 / 90$ & 17 & 18 & 20 & 23 & 22 & 20 \\
\hline $90 / 91$ & 18 & 17 & 16 & 13 & 18 & 16 \\
\hline $91 / 92$ & 21 & 36 & 25 & 22 & 23 & 25 \\
\hline $92 / 93$ & 30 & 23 & 25 & 18 & 24 & 24 \\
\hline $93 / 94$ & 21 & 18 & 18 & 18 & 13 & 18 \\
\hline $94 / 95$ & 18 & 25 & 23 & 9 & 25 & 20 \\
\hline $95 / 96$ & 22 & 19 & 20 & 18 & 19 & 20 \\
\hline $96 / 97$ & 21 & 25 & 20 & 17 & 20 & 21 \\
\hline $97 / 98$ & 20 & 24 & 20 & 20 & 24 & 22 \\
\hline 98/99 & 29 & 26 & 27 & 25 & 20 & 25 \\
\hline $99 / 00$ & 26 & 26 & 27 & 10 & 12 & 20 \\
\hline 00/01 & 24 & 24 & 18 & 17 & 22 & 21 \\
\hline $01 / 02$ & 19 & 19 & 19 & 26 & 21 & 21 \\
\hline $02 / 03$ & 19 & 17 & 19 & 16 & 17 & 18 \\
\hline $03 / 04$ & 16 & 17 & 14 & 20 & 18 & 17 \\
\hline $04 / 05$ & 25 & 12 & 20 & 10 & 17 & 17 \\
\hline $05 / 06$ & 20 & 14 & 13 & 18 & 22 & 17 \\
\hline 06/07 & 23 & 21 & 21 & 22 & 21 & 22 \\
\hline $07 / 08$ & 12 & 13 & 18 & 21 & 20 & 17 \\
\hline 08/09 & 20 & 18 & 6 & 24 & 23 & 18 \\
\hline Average & 21 & 22 & 21 & 20 & 21 & 21 \\
\hline
\end{tabular}

\section{Correlation between Planting Date and SST Anomaly}

Based on research results Naylor et al. (2002) and the correlation between the SSTA and the onset of the rainy season on the preliminary study, SSTA used in this study is the SSTA in August the previous year. The correlation between planting date and SST anomaly for five clusters in Indramayu can be explained more detail by the figures 3 and 4 .

The most significant correlation is in Lohbener, where it has $\mathrm{R}-\mathrm{Sq}=45 \%$ (Figure 3 ) and forecast skill $=64.52 \%$. The higher SST anomaly correlated to the greater of the delay in the planting dates. This happens because when in the Nino 3.4 region has low pressure anomaly caused by the high SST, Indonesia to have eastward wind anomalies. This results in anomalous high pressure over Indonesia, including Indramayu areas, which often causes dryer weather and delays in the rainy season. 


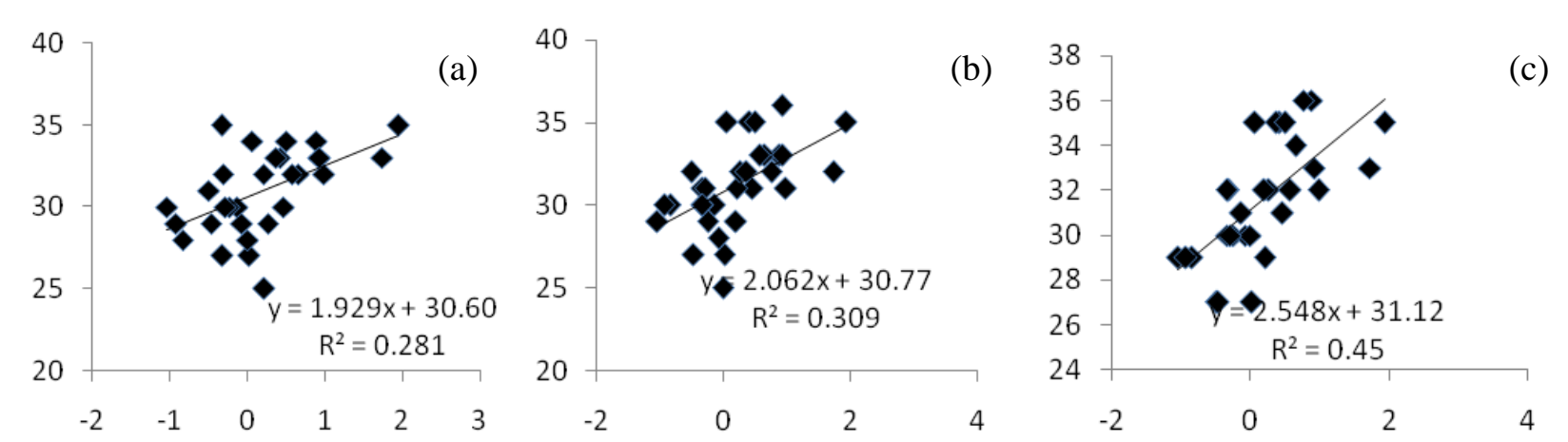

Figure 3 Scatterplot of planting date vs SST anomalies for August in Bondan (a), Bangkir (b) and Lohbener (c).
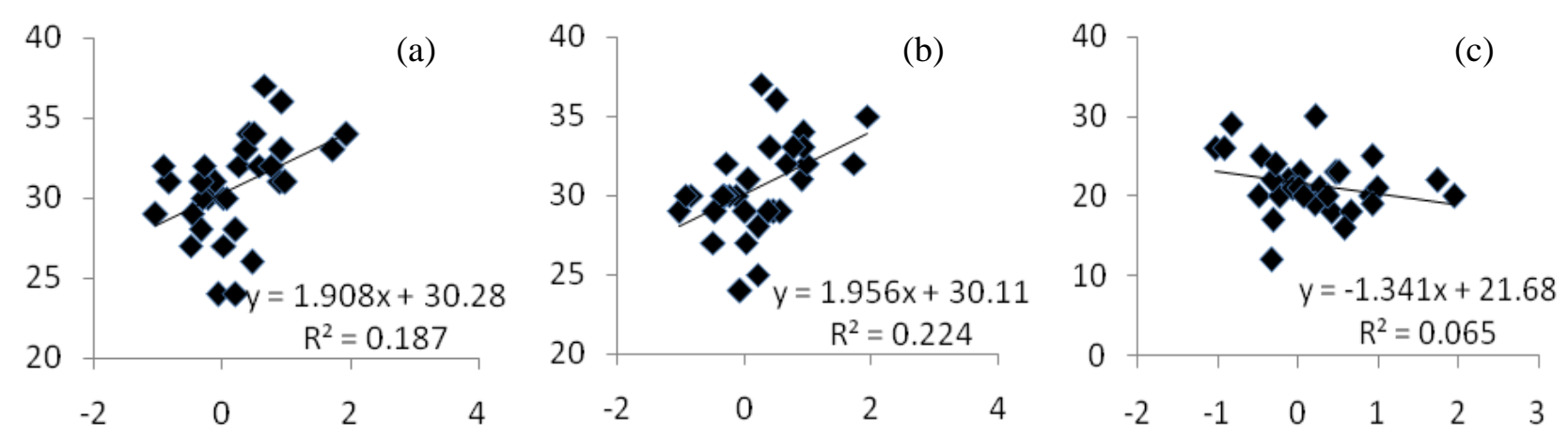

Figure 4 Scatterplot of planting date vs SST anomalies for August in Bulak (a), Cikedung (b) and Bondan (c).
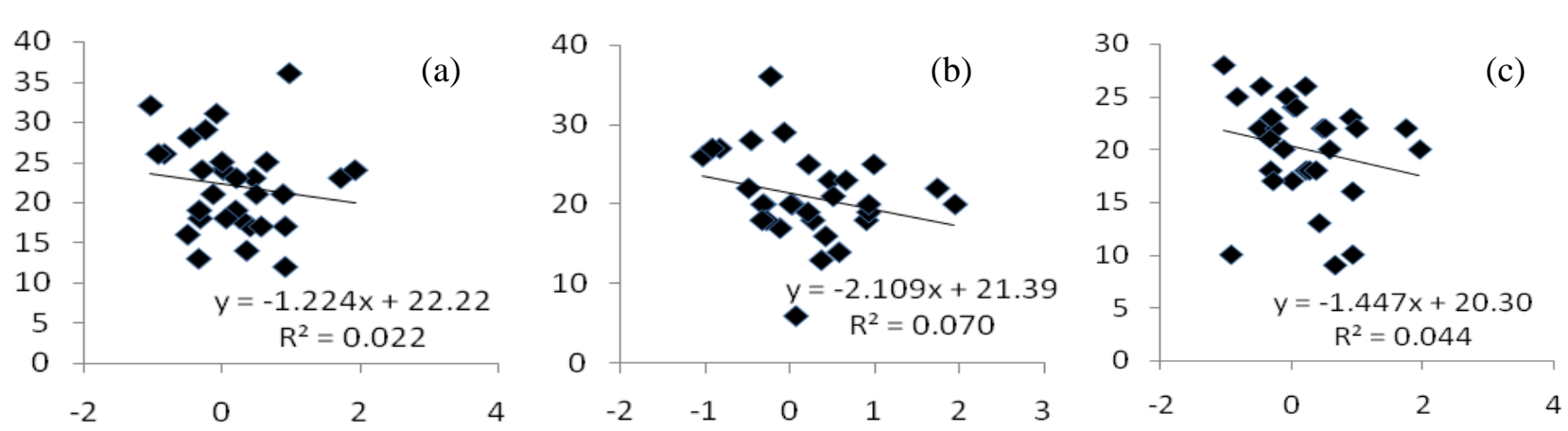

Figure 5 Scatterplot of growing season vs SST anomalies for August in Bangkir (a), Lohbener (b) and

Bulak (c).

\section{Correlation between Growing Season and SST Anomaly}

The station with the greatest amount of variability explained is Lohbener, where $\mathrm{R}-\mathrm{Sq}$ is only $7 \%$. SST Anomalies cannot explain the growing season with high accuracy. In teorities, the higher SST anomaly value at Nino 3,4 will make Indonesia may become a center of high pressure and cause to diverge at the surface over Indonesia which makes it dryer and shortens the growing season. The best equation to predict the planting date and growing season are obtained from the regressions based on the correlation with the SST anomalies (Table 3). The correlation between planting date and SST anomaly for five clusters in Indramayu can be explained more detail by the Figure 5 .

\section{Forecast Skill}

The forecast skill for the models show the model skill to forecast the advanced planting date. The areas below ROC line for advanced planting date in Bondan, Bangkir, Lohbener, Bulak, and Cikedung are $0.84,0.76,0.84,0.68$, and 0.60 respectively. All the areas below the line are more than 0.50 . It indicates that the model skill to forecast advanced planting date is positive, means that the model is reliable enough to be used. Although there is part of line below the non skill line, means non reliable skill, the areas below the ROC curve is still more than 0.50. Bondan and Lohbener show the best forecast skill among others. 
Decade

$\begin{array}{llllllllllllllllllllllllllllllllll}22 & 23 & 24 & 25 & 26 & 27 & 28 & 29 & 30 & 31 & 32 & 33 & 34 & 33 & 36 & 1 & 3 & 4 & 6 & \text { / } & 8 & 9 & 10 & 11 & 12 & 13 & 14 & 15 & 16 & 17 & 18 & 19 & 20 & 21\end{array}$

V.

Recommended plantation: Rice - Secondary Crop - Fallow

Figure 6 Cropping calendar for Lohbener (SST anomaly August $=0$ ).

Decade

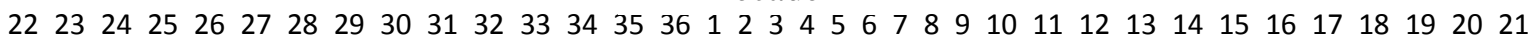

12

Recommended plantation: Short Age (genjah) Rice - Vegetable crop - Fallow

Figure 7 Cropping calendar for Lohbener (SST anomaly August $=2$ ).

Decade

$\begin{array}{llllllllllllllllllllllllllllllllllll}22 & 23 & 24 & 25 & 26 & 27 & 28 & 29 & 30 & 31 & 32 & 33 & 34 & 35 & 36 & 1 & 2 & 3 & 4 & 5 & 6 & 7 & 8 & 9 & 10 & 11 & 12 & 13 & 14 & 15 & 16 & 17 & 18 & 19 & 20 & 21\end{array}$

W

Recommended plantation: Rice - Rice - Fallow

Figure 8 Cropping calendar for Lohbener (SST anomaly August $=-2$ ).

$=$ Preparation

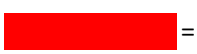

Growing Season

\section{Cropping Calendar}

Land preparations can be conducted three decades before the planting date. The farmer can seed and cultivate the land in this period. One decade after the growing season can still be considered as the harvest time, because commonly the plant does not need water close to the harvest (Figures 6 - 8).

Several weakness occur during the process which may result in some errors. For example, the assumption of identical temperatures for all areas, the temperature variability that does not perfectly reflect reality and neglecting other factors besides SST anomalies can lead to errors.

\section{CONCLUSION}

The planting date can be formed based on August SST anomalies. Lohbener has the best correlation between SST anomalies for August with planting date with $\mathrm{R}-\mathrm{Sq}=45 \%$ and forecast skill more than $75 \%$ and growing season with $\mathrm{R}-\mathrm{Sq}=$ 7\%. The August SST anomalies can explain the planting date, but can't explain the growing season acurately. By inputting the August SST anomaly data to the obtained equation, it can be organized the cropping calendar which consists the period of time devoted to land, seed preparation, and planting, crop growing, as well as the final harvest.

\section{REFERENCES}

Adams RM, Houston LL, McCarl BA, Tiscareño LM, Matus GJ, Weiher RF. 2003. The benefits to Mexican agriculture of an El Niño-southern oscillation (ENSO) early warning system. Agricultural and Forest Meteorology 115 (2003) 183-194.

Boer R. 2006. Metode untuk Mengevaluasi Keandalan Model Prakiraan Musim. Paper presented in Downscaling Model Training, Meteorological,Climatological, and Geophysics Agency, Jakarta, September 16-18, 2006.

[BPS] Badan Pusat Statistik. 2009. Indramayu dalam Angka Tahun 2008. Indramayu.

Hansen J. W., Hodges A. W., and Jones J. W. 1998. ENSO Influences on Agriculture in the Southeastern United States. J. Climate, AMS (11): 404-411.

Haryoko U. 2008. Pewilayahan Hujan untuk Menentukan Pola Hujan (Contoh Kasus Kabupaten Indramayu). Jakarta: BMKG.

Moron V., Robertson A. W. and Boer, R. 2009. Spatial Coherence and Seasonal Predictability of Monsoon Onset over Indonesia. J. Climate, 22, 840-850.

Naylor RL., Falcon WP., Rochberg D., and Wada N. 2001. Using El Nino/Southern Oscillation Climate data to Predict Rice Production in Indonesia. Climate Change, 50:255-265.

Naylor RL., D.S. Battisti, D.J. Vimont W.P. Falcon, dan M.B. Burke. 2007. Assessing the risks of climate variability and climate change for Indonesian rice agriculture. Proc. Nat. Acad. Sci. 104 : 7752-7757. 
Narapusetty B, Delsole T, and Tippett K. 2010. Optimal Estimation of the Climatological Mean. Calverton: Center for Ocean Land Atmospheric Studies.

Robert MG, Dawe D, Falcon WP, Naylor RL, 2008. ElNino_Southern Oscillation Impacts on Rice production in Luson, Phillipines, J. of Appl. Meterology and Climatology, American Meteorology Society, 48: 1718-1724.

Ropelewski CF and Halpert MS. 1989. Precipitation Pattern Associated with the high Index Phase of the Southern Oscillation. J of Climate (2): 268-284.
Pawitan H, Las I, Suharsono H, Boer R, Handoko, Baharsjah J. 1997. Implementasi Pendekatan Strategis dan Taktis Gerakan Hemat Air. dalam: Sumberdaya Air dan Iklim dalam Mewujudkan Pertanian Efisiensi. Jakarta: Departemen Pertanian.

White M and Host G. 2002. An Assessment of Potential Evapotranspiration for the Northern Lake States. Duluth: University of Minnesota. 